Y.-L. ZHONG*, M. WEISEL, G. R. HUMPHREY, D. J. MUZZIO, L. ZHANG, M. A. HUFFMAN, W. ZHONG, K. M. MALONEY, K. R. CAMPOS (MERCK \& CO., INC., RAHWAY, USA)

Scalable Synthesis of Diazeniumdiolates: Application to the Preparation of MK-8150

Org. Lett. 2019, 21, 4210-4214.

\section{Synthesis of MK-8150}<smiles>C=CCNC(C)(C)C</smiles>

A

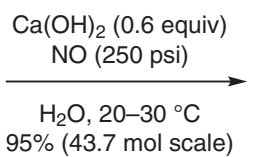

(29 examples)<smiles>C=CCN(/[N+]([O-])=N/O[Hg]O/N=[N+](\[O-])N(CC=C)C(C)(C)C)C(C)(C)C</smiles>

B<smiles>C/C=C/N1CCC(OS(=O)(=O)c2ccc(C(F)(F)F)cc2)CC1</smiles><smiles>C=CCN(/[N+]([O-])=N/OC1CCN(c2ccc(C#N)cn2)CC1)C(C)(C)C</smiles>

$\mathrm{NaBH}_{4}$ (1.24 equiv) $\mathrm{Pd}(\mathrm{OAc})_{2}$ ( 0.010 equiv) DPPP ( 0.015 equiv) $\mathrm{EtOH}, 40-45^{\circ} \mathrm{C}, 4 \mathrm{~h}$ $93 \%(27.9 \mathrm{mmol}$ scale)<smiles>CC(C)(C)N(N=[N+]([O-])OC1CCN(c2ccc(C#N)cn2)CC1)[13C](=O)[O-]</smiles>

Significance: Nitric oxide (NO) plays a key role in the regulation of cardiovascular, immune, and nervous systems. Diazeniumdiolate (DAZD)-based NO donors release two equivalents of $\mathrm{NO}$ at $\mathrm{pH} 7.4$ and $37^{\circ} \mathrm{C}$, thereby enabling modulation of NO concentration in cellular environments and control physiological processes. MK-8150 is a DAZD NO donor and a potent and significant blood-pressurelowering drug candidate.
Comment: The synthesis of MK-8150 depicted is based on an efficient synthesis of stable diazeniumdiolate calcium salt $\mathbf{B}$ by reaction of secondary amine A with $\mathrm{NO}$ at high pressure (250 psi) in water containing calcium hydroxide. Under these conditions calcium salt B precipitated driving the reaction to completion. O-Alkylation of calcium diazeniumdiolate salt $\mathbf{B}$ followed by reductive deallylation afforded MK-8150 in 85\% yield from C.

- Use of barium hydroxide or magnesium hydroxide in place of calcium hydroxide gave lower yields.

- 29 examples; yields typically $>90 \%$ yield (four exceptions)

\section{Category}

Synthesis of Natural

Products and

Potential Drugs

\section{Key words}

MK-8150

diazeniumdiolates

nitric oxide 